\title{
Separating and Washing Coffee Harvested With Plastic Nets'
}

\author{
L. E. Cancel, J. M. Rivera-Ortiz, and M. C. Ruiz de Montalvo ${ }^{2}$
}

\section{INTRODUCTION}

Coffee harvesting, as practiced in most of the coffce-producing regions of the world, is a high labor-consuming operation. In addition, heavy losses of coffee berries also occur during the picking operation (2). Coffee regions with acute labor shortages, high labor costs, and high land values need to change present methods of harvesting and processing.

A low-cost method for harvesting coffec, developed by Vicente-Chandler, Silva, and Abruña (4), "reduces labor requirements to less than one third and increases yields of harvested coffec by over 50 percent as compared with current practices, by reducing field losses of coffee." This low-cost harvesting method, particularly suitable to high-yielding coffee plantations, consists of spreading plastic nets to cover the ground and collecting the material deposited on the nets every 4 to 6 weeks. The collected material consists of a mixture of leaves, coffec beans, and berries.

Coffee harvested by net must be separated from the foreign matter for processing. No known method presently exists for this purpose. This report presents a method developed for separating and cleaning coffee harvested with plastic nets.

\section{MATERIALS AND METHODS}

\section{MATERIAL COLLECTED ON NETS}

The material deposited on the nets consists of an extraordinary large volume of leaves mixed with coffec beans and berries in various phases of fermentation; also, a large amount of twigs of different size and decomposed vegetative matter.

The mechanical behaviour of this deposited mixture is unpredictable due to its heterogeneous composition. Its physical characteristies also are affected by weather conditions prevailing during harvest time. The degree of humidity prevailing during harvest conditions the deposited material. The material erollected tends to cake on the nets during prolonged overcasts and drizzly spells. Some leaves start to rot, others become saturated

1 Manuseript submitted to Editorial Board June 10, 1971.

2 Food Scientist and Research Assistants, respectively, Food Technology Laboratory, Agricultural Experiment Station, Mayagüez Campus, University of Puerto Kico, Río Piedras, P. R. 
with water, and these acquirc a large degree of stickiness which hinders separation of coffee from foreign material. Dry windy weather during the coffee collecting period, on the other hand, results in a completely loose conglomerate; the leaves become crisp and light in weight and such material can be handled easily during the coffee bean separation.

The material deposited on the nets is bulky because of the large amount of leaf material. In measurement, it was found that such material deposited on 266 nets (each 20 feet by 10 feet) could be packed with very little pressure into 190 cubic feet although its actual volume was about 400 cubic feet. The volume of the total is independent of the amount of coffee contained. Coffee beans and berries accommodate or set in the void spaces formed by the leaves and thus contribute little or none to the volume, although there is a tendency for the coffec to settle on the bottom of the pile on handling.

SEPARATION OF TRASH FROM THE COFFEE BEANS AND BERRIES

The coffee was collected according to the method described by VicenteChandler (4). The collected material was taken to the pilot plant and processed the following day. The separation of the coffee from foreign material was carried out in an air tunnel, designed and constructed at the Food Technology Department (fig. 1) (1). It consists of a blade-type blower placed in a two-chamber tunnel. When the material collected on nets is fed into the separator, the light components are separated in the upper chamber, while the heavier fall into the bottom chamber where a strong air current separates most of the remaining foreign substances from the coffee. The material is placed in a holding bin from where it is lifted and fed into the air tunnel inlet by means of a conveyor. The conveyor also serves as a constant feeding device. The amount fed into the separating machine can be reduced or increased by lowering or increasing the speed of the conveyor. For wet and sticky material, the feed can be reduced to obtain good separation. When the material is loose and dry, the rate of feeding can be raised to a maximum.

In the machine used, the separated eoffee beans and berries are obtained through a discharge opening at the bottom of the tunnel. Part of the forcign material, mostly small twigs and nearly dry leaves, are discharged through a side opening of the tunncl, and the othor part, mostly large twigs and hravily wet and sticky leaves, come out of the rear end of the tunnel.

CLEANING AND WASHING OF COFFEE BEANS

A horizontal coffee washing machine, manufactured by "Maquinaria Cafetalera" of Bayamón, Puerto Rico, (fig. 2) was used for cleaning the coffec beans. This machine is a 57 -inch eylinder unit with a vibrating screen at the discharge end and is run by a 5 -horsepower motor. It consists 


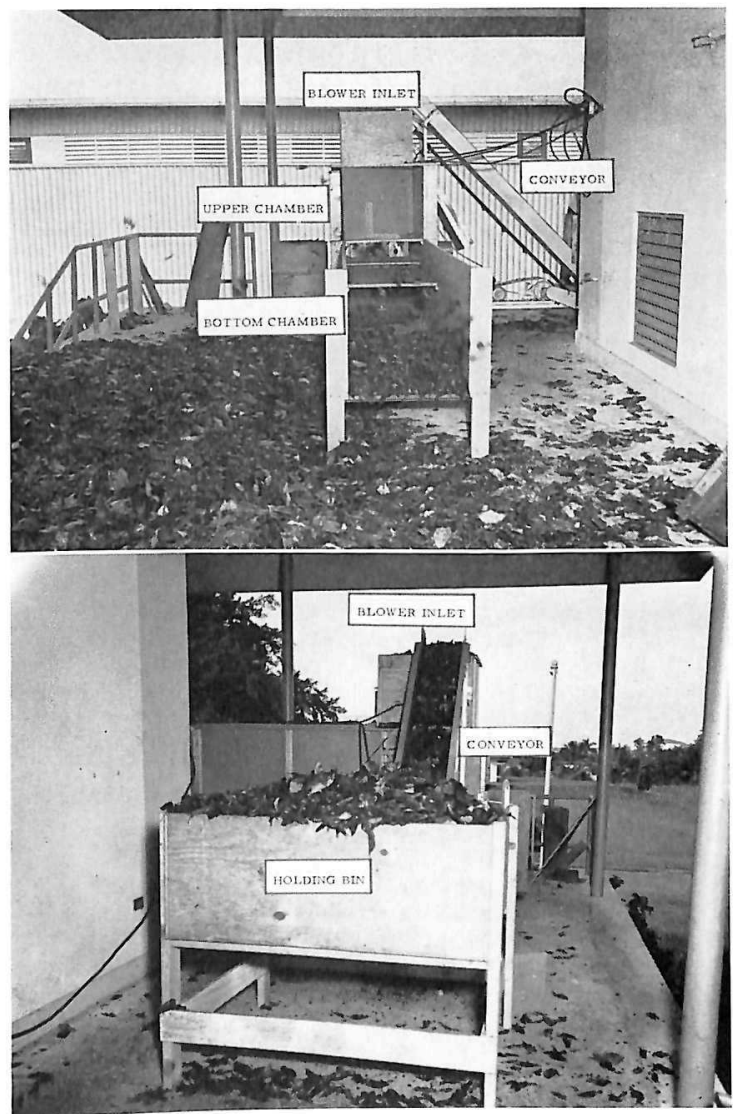

Fig. 1 End and side view of a single level arrangement for a coffee blower, 


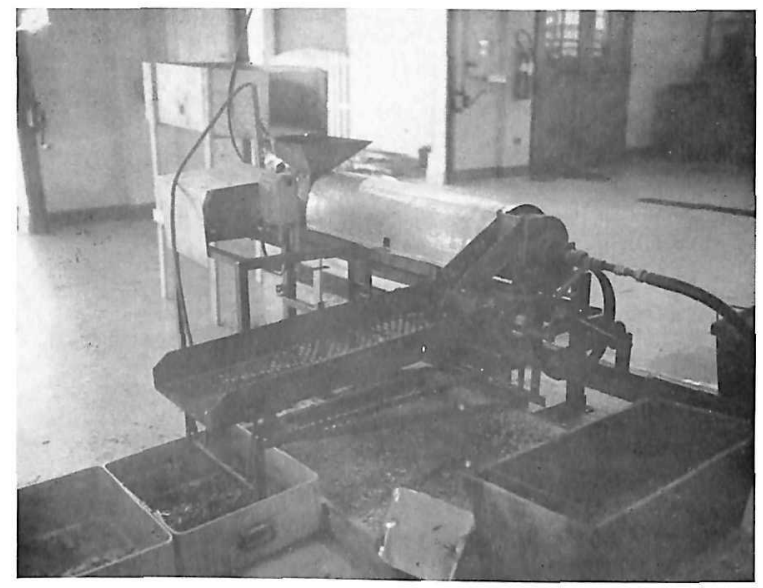

Frg. 2.-Coffee washing machine.

basically of a horizontal axis with radial spokes, rotating inside a slotted cylinder at about 790 r.p.m. The model employed was one of several deseribed by Sivetz and lioote (3) designed to rub off the mucilage from pulped coffee by attrition or serubbing. The material fed, which ennsists mainly of coffee beans and berries together with some extraneous matter, is pressed against each other and against the slotted wall of the eylinder while being forcibly fed through the machine by inclined vanes attached to the rotating axis. Additional rubbing action is obtained by the large number of spokes attached to the main axis. Once this machine is in operation and stabilized, the amount of material discharged is controlled by the rate of feeding. Water is injected into the cylinder at the discharge end through the main axis which is hollow and properly perforated along its length to insure a uniform distribution of the water.

\section{RESULTS AND DISCUSSION}

The pilot plant experiments on the separation and washing of eoffee harvested with plastie nets were condueted during the 1969 eoffere seatson. Full information of the process under evaluation was obtained for the 
TABL: 1.-Resulls oblained by using the air lunnel separalor in the cleaning of coffee collecled from a 4-acre planlation

\begin{tabular}{|c|c|c|c|c|c|c|}
\hline Collection & $\begin{array}{l}\text { Time nets } \\
\text { lefifon } \\
\text { ground }\end{array}$ & $\begin{array}{l}20 \text { foot- } \times 10 \\
\text { foolt-nets } \\
\text { collected }\end{array}$ & $\begin{array}{l}\text { Visual evaluation } \\
\text { of material on } \\
\text { nets }\end{array}$ & 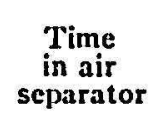 & $\begin{array}{l}\text { Weight of } \\
\text { coffee } \\
\text { separated }\end{array}$ & $\begin{array}{l}\text { Weight of } \\
\text { washed } \\
\text { cofee } \\
\text { beans }\end{array}$ \\
\hline \multicolumn{7}{|c|}{ Rainy seasons } \\
\hline \multirow{5}{*}{ Second } & Wecks & Number & & Hours & Pounds & Pounds \\
\hline & \multirow{4}{*}{5} & $260^{2}$ & $\begin{array}{l}\text { Soggy leaves, } \\
\text { very wet mate- } \\
\text { rial }\end{array}$ & 6.25 & 1,913 & 1,042 \\
\hline & & 188 & Practically dry & 2.75 & 1,040 & 789 \\
\hline & & 207 & Very wet & 4.00 & 1,181 & 804 \\
\hline & & $226^{2}$ & Very wet & 4.00 & 1,704 & 1,185 \\
\hline \multicolumn{7}{|c|}{ Dry season } \\
\hline \multirow{4}{*}{ Third } & \multirow{4}{*}{ 6 } & 26.4 & Practically dry & 2.25 & 333 & 236 \\
\hline & & 300 & Practically dry & 3.00 & 410 & 345 \\
\hline & & $252^{2}$ & Practically dry & 2.75 & 511 & 454 \\
\hline & & 71 & Practically dry & 1.00 & 214 & 202 \\
\hline
\end{tabular}

1 The contents of these 266 nets were packed into 189 cubic feet.

Ten 30-foot $\times 10$-foot nets included.

second and third collections of nets. The results are given in table 1, showing the figures for the performance of the air scparator.

It required 17 hours of air separator operation to clean the coffee from 4 acres of a high-yielding plantation, when the material was collected during a period of constant rain and the nets sometimes gathered while rinining. Under conditions such as these, coffee production from 1 acre was processed in 4.25 hours; therefore, an average of about 2 acres may be processed in an S-hour run.

These figures indicate that the air separator used in these experiments has a capacity to handle such material collected from 50 acres if the nets remain on the ground for periods of 5 weeks. This can be accomplished by collecting 2 acres of nets per day, 5 days a week.

These projections are within safe bounds because some windy and sunny periods can be expected during the coffee harvesting season when the material collected can be run through the air separator in about half the time on which our projections are based. The results obtained for the third net-collecting period, which corroborate the above statement, also are presented in table 1 . It required 9 hours for the material collected during the third period to run through the air separator. This is an average of about 2 hours of operation for the material collected from 1 acre, which 
doubles the figures obtained for the capacity of the air separator, thus increasing it to 4 acres per day.

The results of the washing operation using the 57 -inch horizontal washing machine indicate that this unit has a capacity to handle about 1,000 pounds of clean coffee beans per hour. In these experiments it was observed that in a single operation the machine pulped the whole berries, disintegrated and eliminated the remaining twigs and leaves, destroyed and washed out the coffee pulp, and cleaned the coffee beans. Most of the green coffee berries in the mixture were pulped, and those which remained whole were separated in the shaker screen at the discharge end of the machine. The twigs which were not destroyed and eliminated in the machine also were separated in the shaker screen.

\section{SUMMARY}

A method was developed for cleaning and washing coffee harvested with plastic nets. The material colleeted was bulky due to large amounts of leaves. An air separator designed and constructed to separate foreign material from coffee beans and berrics is described. It consists of a bladetype blower placed in a two-chamber tunnel. When the net-collected material is fed into the separator, the light components are separated in the upper chamber, while the heavier materials fall into the bottom chamber where a stronger air current separates most of the remaining foreign substances from the coffec.

Separation of the material was more difficult when weather conditions were rainy or humid while the nets were on the ground. The separation was much easier when the material was collected during dry, windy weather. The capacity of the air separator for wet and sticky material was about 2 acres per 8-hour run; the eapacity was about 4 acres per S-hour run with dry material.

The material obtained from the air separator consisted of coffee beans and berries, together with some extraneous matter. This material was fed into a horizontal washing machine where the remaining extraneous material was removed leaving the coffee ready for drying.

\section{RESUMEN}

Se desarrolló un método para limpiar y lavar el café recogido en mallas plásticas. El material recogido en las mallas durante la recolección del café era voluminoso debido a la cantidad de hojas que contenía. Para separar el café del material extraño se diseñó y construyó un separador a base de aire. Este consta de dos cámaras de separación y un abanico que provee la corriente de aire necesaria. Cuando se alimentó el separador con el material recogido en las mallas, los componentes más livianos de la mezcla se separaron en la cámara superior, cayendo los materiales más pesados a la cámara inferior donde la corriente de aire es más fuerte y por tanto separó casi todos los materiales. 
Durante periodos de lluvia constante, el material recogido en las mallas fue dificil de separar, siendo más fácil separarlo durante los períodos de sequía. La capacidad del separador fue de 2 acres por corrida de 8 horas, cuando el material recogido estaba mojado, pero cuando el material estaba seco la capacidad aumentó a 4 acres por corrida de 8 horas.

El café separado se pasó por una máquina horizontal para lavar café. En esta operación se le removió totalmente la materia extraña y se lavó el grano en pergamino, quedando listo para ser secado.

\section{LITERATURE CITED}

1. Cancel, L. E., Rivera-Ortíz, J. M., and García Rivera, F., Machine for Separating Coffee Beans and Berries from Detritus, U. S. Patent Application Serial No. 85, 975, Jan. 12, 1971.

2. Silva, S., Vicente-Chandler, J., and $A$ bruña, F., Field losses of coffee and improved harvesting methods for intensively managed plantations, J. Agr. Univ. P. R. 53 (4) : 268-73, 1969.

3. Sivetz, M. and Foote, H. E., Coffee Processing Technology, Vol. I, The Avi Pulblishing Co., Inc., Westport, Conn., pp. 86-9, 1963.

4. Vicente-Chandler, J., Silva, S., and Abruna, F., $A$ new low-cost method of harvesting coffec in high-yielding plantations, J. Agr. Univ. P.R. 53 (4): 259-67, 1969. 